\title{
HUBUNGAN ORGANIZATIONAL CULTURE DAN INSTRUCTIONAL LEADERSHIP DENGAN KINERJA ORGANISASI HMPS PGSD UNCP PERIODE 2020
}

\author{
${ }^{1}$ Erni, ${ }^{2}$ Andi Kilawati \\ ${ }^{1,2}$ Universitas Cokroaminoto Palopo, Jl. Latamacelling No.19 B, 047122111/ Kota Palopo \\ Email: ernirasyid10@gmail.com
}

\begin{abstract}
Abstrak
Penelitian ini bertujuan untuk mengetahui hubungan organizational culture dan Instructional leadership dengan Kinerja Organisasi HMPS PGSD Universitas Cokroaminoto Palopo Periode 2020. Penelitian ini merupakan penelitian kuantitatif korelasional. Hipotesis penelitian ini diuji dengan analysis varians (ANAVA) dua jalur. Sampel penelitian ini adalah pengurus HMPS PGSD UNCP Periode 2020, sejumlah 15 orang. Hasil penelitian ini menunjukkan bahwa terdapat hubungan positif antara organizational culture dan instructional leadreship dengan kinerja organisasi. Berdasarkan hasil penelitian dapat disimpulkan bahwa semakin positif organizational culture dan semakin positif instructional leadership, berkontribusi pada peningkatan kinerja organisasi HMPS PGSD Universits Cokroaminoto Palopo Periode 2020.
\end{abstract}

Kata Kunci: Organizational Culture, Instructional Leadership, Kinerja Organisasi

\begin{abstract}
This study aims to determine the relationship between organizational culture and instructional leadership with the organizational performance of HMPS PGSD Cokroaminoto Palopo University Period 2020. This research is a correlational quantitative research. The research hypothesis was tested using two-way analysis of variance (ANOVA). The sample of this research is the management of the 2020 HMPS PGSD UNCP, a total of 15 people. The result of this study indicate that there is a positive relationship between organizational learning and instructional leadership with organizational performance. Based on the results of the study, it can be concluded that the more positive organizational culture and the more positive instructional leadership, contribute to improving the organizational performance of HMPS PGSD Cokroaminoto Palopo University for the 2020 period.
\end{abstract}

Keywords: Organizational Culture, Instructional Leadership, organizational performance 


\section{PENDAHULUAN}

Tujuan bergabung pada organisasi kemahasiswaan adalah untuk menemukan jati diri kepemimpinan. Banyak organisasi kemahasiswaan yang menjadi pilihan bagi mahasiswa untuk mengaktualkan potensi diri, HMPS (Himpunan Mahasiswa Progran Studi) PGSD adalah salah satu pilihan yang banyak diminati oleh mahasiswa di Program Studi yang menjadi primadona bagi mahasiswa Prodi PGSD Universitas Cokroaminoto Palopo.

Pengurus HMPS PGSD sebagai pelaku organisasi kerap kali tampil berbeda pada kancah kegiatan kemahasiswaan dan pada perkuliahan formal. Banyak aktualisasi yang mewujud selama periode 2020, namun fenomena lai terjadi bahwa beberapa pengurus mengundurkan diri dari jabatan yang menjadi tanggung jawabnya di tubuh HMPS PGSD UNCP (Dr. Meithiana Indrasari, S.T. 2017) . Beberapa point penyebab beberapa pengurus mengundurkan diri adalah, 1) ingin fokus pada bidang akademik, 2) merasa bahwa terdapat ketidak sesuaian antara jati diri dan iklim organisasi, dan 3) tidak mempu mengemban amanah karena tidak memiliki kesadaran exkatologi. Ketiga point ini adalah kesimpulan yang dihasilkan setelah wawancara secara langsung oleh mahasiswa yang mengundurkan diri dari kepengurusan HMPS PGSD.

Sepanjang periode kepengurusan HMPS PGSD (periode 2020), selain fenomena pengunduran diri beberapa pengurus, namun pengurus yang bertahan berhasil menorehkan prestasi dengan menggelar banyak kegiatan dengan melibatkan seluruh mahasiswa PGSD UNCP. Beberapa aktualisasi kegiatan yang telah mewujud adalah porseni, kerja sama dengan dosen pengampuh mata kulia budaya bugis dalam menggelar festival budaya Bugis, berhasil mengadakan pembersihan rumah ibadah yang ada di Kota Palopo, berhasil menggelar jelajah hutan penelitian kayu Lara di Kabupaten Luwu, dan berkontribusi sebagai relawan pada banjir bandang yang melanda Masamba menjelang akhir tahun 2020, Ini adalah kinerja yang ditorehkan oleh Sebagian besar pengurus, namun dibalik kesuksesan mengelar kegiatan dan fenomena pengunduran diri terdapat iklim organisasi yang memicu kondisi tersebut.

Penulis mengamati fonomena tersebut secara tidak langsung dan mencoba berembuk Bersama pengurus inti HMPS PGSD periode 2020 berdiskusi pada November 2020. pengurus yang aktif menggelar kegiatan adalah (Shofiyani and Rahmawati 2019), mereka yang berhasil menjalin hubungan emosional sesama anggota pengurus, 2) pengurus yang 
mengundurkan diri dari jabatan kepengurusan tidak merasa nyaman dengan iklim organisasi, dibuktikan dengan ketidakmampuan berbaur sesama pengurus, 3) penyebab mahasiswa bertahan dan mengundurkan diri sangat dipengaruhi oleh budaya orgnaisasi yang terjadi pada saat itu. Hasil diskusi ini merupakan data yang belum valid, karena belum dilaksanakan penelitian sekaitan hal tersebut pada waktu diskusi berlangsung.

Sebagai referensi awal untuk mengkaji lebih dalam dasar penelitian ini adalah teori Stroch (dalam Andi Kilawati, 2017: 3) menyatakan: "Every organization has its own organizational culture-a system of shared values about what is important and beliefs about how things work that produce the norms and expectations of performance" maksudnya adalah setiap organisasi memiliki budayanya sendiri. Inilah yang menjadi sistem nilai dan menjadi pedoman bagi anggota dalam mengaktualkan kinerja.

Senada dengan Stroch, Stephen Robins (dalam Andi Kilawati: 2017:7) mengatakan bahwa organizational culture refer to a system of shared meaning held by members that distinguishes the organization. This system of shared meaning is a set of characteristics that the organization values" Budaya organnisasi adalah system nilai yang dianut oleh anggota organisasi. Inilah yang membedakan tiap-tiap organisai yang ada.

Budaya organisasi (Latifa, Marini, and Maksum 2021) sebagai sistem yang dianut oleh anggotanya sangat berhubungan dengan kepemimpinan (leadership) yang mengaktual pada kinerja nyata para anggota. Seperti kata Colquitt, lepine, dan Wesson dalam Andi Kilawati “...the use of power and influence to direct the activities of followers toward goal achievement". Maksudnya adalah leadership merupakan kemampuan menggunakan kekuasaan dan pengaruh sehingga kita dapat menggerakkan segala aktivitas untukmencapai tujuan. Teori Colquitt ini dapat ditemukan pada program kerja HMPS PGSD yang diaktualkan oleh sejumlah pengurus HMPS PGSD yang nyata menampakkan keaktifan pada saat mengikuti perkuliahan.

Pengurus HMPS PGSD yang aktif dan berhasil menggelar kegiatan berbobot adalah mereka yang betah dengan kondisi organisasi, berhasil menjalin hubungan emosional sesame pengurus dan aktif pada setiap agenda organisasi dan berkecimpung secara rutin pada kajian lintas Angkatan yang digelar 1 kali dalam 2 minggu. Sebenarnya inilah yang menjadi dasar penelitian korelasional ini dilaksanakan, untuk mendapatkan data valid terkait hubungan organizational culture dan instructional leadership dengan kinerja organisasi. 
Penelitian ini nyata memberikan kintribusi faktual berupa sumbangsih studi hubungan yang dapat menjadi rujukan mahasiswa dan dosen dalam lingkup PGSD UNCP untuk membangun budaya organisasi yang positif mengembangkan leadership yang positif guna meningkatkan kinerja dalam lingkup berorganisasi maupun dalam lingkup perkuliahan.

\section{METODE PENELITIAN}

Informasikan secara ringkas mengenai materi dan metode yang digunakan dalam penelitian, meliputi subyek/bahan yang diteliti, alat yang digunakan, rancangan percobaan atau desain yang digunakan, teknik pengambilan sampel, variabel yang akan diukur, teknik pengambilan data, analisis dan model statistik yang digunakan (Sugiono 2016).

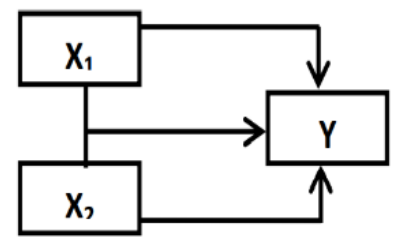

Gambar 1. Konstelasi Penelitian

Keterangan:

$\mathrm{X}_{1} \quad$ :Organizational Culture

$\mathrm{X}_{2} \quad$ : Instructional Leaderhip

Y : Kinerja organisasi

Populasi target dalam penelitian ini adalah seluruh pengurus HMPS PGSD periodel 2020, sedangan polulasi terjangkau adala pengurus HMPS PGSD UNCP periode 2020 sebanyak 15 orang yang dihitung dengan rumus Taro Yamane:

$$
n=\frac{N}{N d^{2}+1}
$$

Keterangan:

$\mathrm{n} \quad$ : Jumlah sampel yang akan ditetukan

$\mathrm{N} \quad$ : Jumlah populasi

$d^{2} \quad$ : Presisi yang ditetapkan (10\%)

Penilaian variabel organizational culture dalam bentuk angket dengan menggunakan skala likert dan 25 butir pertanyaan. Penilaian variabel instructional leadership menggunakan 
skala likert dalam bentuk angket dengan 23 butir pertanyaan, sedangkan penilaian variabel kinerja organisasi dalam bentuk angket dengan menggunakan skala likert sejumlah 30 butir pertanyaan.

Penelitian ini menggunakan analisis deskriptif yang menyajikan 3 hal: 1) penyajian dada dalam bentuk histogram, 2) ukuran pemusatan data meliputi mean; rerata, median, dan modus, 3) ukuran penyebaran data yaitu rentang skor varians dan simpangan baku /standar deviasi.

Data deskirptif penelitian ini disajikan pada tiga variable yaitu: variable (Y) kinerja organisasi, variable $\left(\mathrm{X}_{1}\right)$ organizational culture, dan variable $\left(\mathrm{X}_{2}\right)$ instructional leadership. Sedangkan analisis variable inferensial menyajikan tiga hal, yaitu: uji korelasi, uji korelasi ganda, dan uji signifikansi.

\section{HASIL DAN PEMBAHASAN}

Hasil penelitian ini dideskripsikan sebagai berikut:

\section{Hubungan antara organizational culture $\left(\mathrm{X}_{1}\right)$ dengan Kinerja Organisasi $(\mathrm{Y})$}

Setelah dilakukan penelitian didapatkan hasil bahwa, terdapat hubungan positif organizational culture $\left(X_{1}\right)$ dengan leadersip $\left(X_{2}\right)$. Terdapat hubungan organizational culture dengan leadership pada pengurus HMPS PGSD Universitas Cokroaminoto Palopo sebagai sebuah organisasi. Hal ini dibuktikan dengan hasil penelitian yang menunjukkan adanya koefisien korelasi 4, 883 dan kontrubusi determinasi 23,4\%, yang dijelaskan melalui persamaan regresi $\mathrm{Y}=28,927+0,773 \mathrm{X}_{1}$. Ini maknanya adalah semakin baik organizational culture yang positif akan berkontribusi pada pembentukan leadership setiap pengurus. Organizational culture ini sangat diperlukan untuk membentuk mahasiswa yang berprestasi pada bidang akademik maupun Lembaga.

Hasil penelitian ini diperkuat oleh teori Colquitt bahwa (Kim 2020) "a recent meta alaysis illustrated the importance of person organization fit to employees when feel that their values and personality mtch those of the organization, they experience higher levels of job satisfaction and feel less stress about their day to day tasks. They also feel higher levels to trust toward their managers. Taken together, those result illustrate why person organization fit is so highly correlated with organizational commitment, one of the two outcome in our integrative model of $O B$ when employees feel they fit with their organizational culture" 
Terdapat beberapa hal yang sangat berhubungan dengan budaya organisasi. Ketika pengurus organisasi merasa bahwa nilai kepribadianmereka sesuai dengan kondisi organisasi, maka mereka akan berkontribusi untuk melakukan kinerja pada organisasi tersebut.

Organizational culture (Méndez Prado, Alvarado Sánchez, and Rosado Anastacio 2019) (budaya organisasi) dalam hal ini memiliki peranan penting bagi efisiensi pelaksanaan kinerja organisasi. Budaya organisasi yang berfungsi dengan baik berkontribusi pada efisiensi kinerja organisasi secara sigrnifikan. Pada kondisi budaya organisasi dalam tubuh pengurus HMPS PGSD UNCP terdapat Etika antar kelompok yang sangat menentukan hubungan emosional dan fungsional yang membingkai terjadinya kinerja yang efektif dan efisien.

\section{Hubungan Instructional Leadership $\left(\mathrm{X}_{2}\right)$ dengan Kinerja Organisasi ( $\left.\mathrm{Y}\right)$}

Terdapat hubungan positif antara instructional leadership dengan kinerja organisasi pada pengurus HMPS PGSD UNCP Periode 2020. Hal ini dibuktikan dengan koefisien korelasi 3, 454 dan kontribusi distriminasi 7,0\%, yang dijelaskan melalui persamaan regresi $\mathrm{Y}=57,823+0,6 \mathrm{X}_{2}$. hal ini maknanya adalah, instructional leadership berkontribusi positif dalam meningkatkan kinerja organisasi.

Temuan penelitian ini diperkuat oleh teori Peter ducker bahwa "leadership is not making friends and influencing people. Leadership is the lifiting of man's vision to higher sights, the raising of mans performance the higher standards, the building of mans performance to higher standards, the building of mans personality beyond its normal limitations.

Temuan penelitian ini lebih jauh diperkuat oleh ensiklopedia ilmu social leadership merupakan hubungan antara individu dalam sebuah organisasi. Leadershi dalam HMPS PGSD UNCP merupakan pemicu hubungan emosional semua individu dalam organisasi tersebut. Leadership dalam hal ini adalah terjadi saling mempengaruhi dan dipengaruhi antara ketua dan anggota untuk mencapai tujuan, saling memberikan motivasi, keteladanan dalam berperilaku, dan menjalankan program kerja yang telah di rencanakan.

Leadership, dalam hal ini sangat erat kaitannya dengan gaya kepemimpinan ketua HMPS. Pelopor Gerakan leadership sangat menunjang kinerja pengurus. Inilah kontribusi nyata ketua HMPS PGSD UNCP untuk mengarahkan, mengorganisasikan, mendukung dan memotivasi anggota. 
Instructional leadership yang positif berkontribusi dalam meningkatkan kinerja secara signifikan, didukung oleh Lusier dan Achua (dalam Mahmuddin Yasin: 2013), bahwa: Know Whem to led and when to follow, influence flowers to support organizational interest, provide direction, set challenging objetives anda lead to charge to achieve them, influence change for continual improvement, enjoy working with people'.

\section{Hubungan antara Organizational Culture $\left(\mathrm{X}_{1}\right)$ dan Instructional Leadership $\left(\mathrm{X}_{2}\right)$ dengan Kinerja Organisasi (Y)}

Hasil penelitian menunjukkan bahwa terdapat hubungan positif secara Bersama-sama antara organizational culture $\left(x_{1}\right)$ dan instructional leadership $\left(\mathrm{X}_{2}\right)$ dengan kinerja organisasi (Y) pada pengurus HMPS PGSD periode 2020. Hasil penelitian ini menunjukkan koefisien korelasi 0,183 dan kontribuso determinasi 27,1\%, yang dijelaskan dengan persamaan regresi $\mathrm{Y}=0,708+0,172 \mathrm{X} 2$.

Makna hasil pengujian statistik ini menunjukkan bahwa, organizational culture secara Bersama-sama dengan instructional leadership memberikan efek/kontribusi positif pada kinerja organisasi. Semakin positif organizational culture dan semakin positif pula instructional leadership maka kinerja organisasi HMPS PGSD UNCP periode 2020 semakin tinggi.

Adi sukmana mengatakan bahwa, organisasi pada dasarnya digunakan sebagai wadah bagi mahasiswa untuk mengekspresikan aspirasi agar tercapai tujuan organisasi tersebut. Keterkaitan hasil penelitian dnegan perkataan Adi Sukmana adalah budaya organisasi yang positif dan instructional leadership yang baik dapat berkontribusi pada aktualisasi Lembaga penyalur aspirasi kemahasiswaan yang mengaktual pada meningkatnya manifestasi kinerja melalui keterlaksanaan program kerja HMPS PGSD UNCP periode 2020.

Pentingnya budaya organisasi bagi kepemimpinan dalam tubuh HMPS PGSD UNCP selaras dengan teori Balzac (2011) bahwa "what a leader pays atentiond to snd how s leader respond to a crisis, deals with disagreement, terats those around him, and behaves in general will all feed into the culture of the orgsnization." Hal-hal yang diperhatikan oleh seorang pemimpin adalah dia menanggapi dengan hal hal yang terjadi di sekitar maupun dalam tubuh organisasi. Pemimpin merupakan sumber panutan, pendorong, sekaligus pengaruh yang mengarahkan semua sumber daya anggota dalam Gerakan melaksanakan kinerja atau program kerja yang telah dicanangkan. 
Pemimpin yang baik harus menjadi teladan, memicu, sekaligus berpengaruh dalam menyatukan anggotanya dalam berbudaya dan meningkatkan kinerja secara signifikan (Hari Gunawan, 2019). Temuan hary gunawan dalam jurnal administrasi dan manajemen ini selaras dengan temuan penelitian pada HMPS PGSD UNCP. Pemimpin mampu mempegaruhi anggota melalui kemampuan membuat anggota mengalami derajat kedudukan yang sesuai dengan jati diri, namun tetap pada Gerakan mencapai tujuan organisasi.

Kinerja menurut mangkunegara (202:22) dalam Arga Satria adalah, hasil kerja baik secara kualitas maupun secara kuantitas yang dilaksanakan oleh sesorang dalam melaksanakantugas dan tanggung jawab yang telah diamanahkan. Kinerja ini sangat dipengaruhi oleh kontsribusi positif dari instructional leadership ketua Lembaga, karena kepemimpinan yang positif mampu mengubah nilai-nilai perilaku anggota organisasi untuk bergerak Bersama menvapai visi dan misi organisasi.

Kinerja merupakan gambaran pencapaian pelaksanaan (achievement) suatu program kegiatan oleh seseorang atau sekelompok orang dalam suatu organisasi. Salah satu factor yang mempengaruhi kinerja adalah faktor budaya organisasi. Semakin positif budaya organisasi maka semakin tinggi kinerja anggota dalam suatu organisasi tersebut.

\section{SIMPULAN DAN SARAN}

Berdasarkan hasil penelitian yang telah dilakukan peneliti, maka ada beberapa hal yang menjadi simpulan :

1. Hasil analisis korelasi sederhana menunjukkan bahwa terdapat hubungan positif antara organizational culture dengan kinerja organisasi pada pengurus HMPS PGSD Universitas Cokroaminoto Palopo periode 2020.

2. Hasil analisis korelasi sederhana menunjukkan bahwa terdapat hubungan positif antara instructional leadership dengan kinerja organisasi pada pengurus HMPS PGSD Universitas Cokroaminoto Palopo Periode 2020.

3. Hasil analisis korelasi sederhana menunjukkan bahwa terdapat hubungan positif secara sederhana antara organizational culture dan instructional leadership dengan kinerja organisasi pada pengurus HMPS PGSD Universitas Cokroaminoto Palopo peride 2020. 


\section{DAFTAR PUSTAKA}

Dr. Meithiana Indrasari, S.T., M.M. Kepuasan. 2017. "Kepuasan Kerja Dan Kinerja Karyawan Tinjauan Dari Dimensi Iklim Organisasi, Kreatifitas Individu, Dan Karakteristik Pekerjaan." Yogyakarta: Indomedia Pustaka: 1-85.

Gunawan, Hari. \& Baharuddin, Agus. (2019). Pengaruh Gaya kepemimpinan dan budaya organisasi terhadap kinerja Karyawan PT.KMPlus. jurnal administrasi dan manajemen. 9 (2), 173-176.

Kilawati, Andi. (2017). Hubungan Budaya Organisasi dan Instructional leadership dengan kepercayaan (sebuah studi korelasional pada Guru Sekolah Dasar di Kecamatan Barru). Jurnal Ilmiah Pendidikan Guru Sekolah Dasar. 1 (1), 1-16.

Kim, Sehoon. 2020. "How a Company's Gamification Strategy Influences Corporate Learning: A Study Based on Gamified MSLP (Mobile Social Learning Platform)." Telematics and Informatics (September). file:///C:/Users/Lenovo/Documents/S3/MOBILE LEARNING/j.tele.2020.101505.pdf.

Latifa, Nur, Arita Marini, and Arifin Maksum. 2021. "Pendidikan Multikultural Di Sekolah Dasar (Sebuah Studi Pustaka).” Jurnal Pendidikan Dasar Nusantara 6: 42-51.

Méndez Prado, Silvia Mariela, María Isabel Alvarado Sánchez, and Joel Alejandro Rosado Anastacio. 2019. "Academic Literacy Program Implementation in an Ecuadorian University: A Multinomial Logit Approach." International Journal of Adolescence and Youth 24(3): 351-61. https://doi.org/10.1080/02673843.2018.1544084.

Shofiyani, Amrini, and Rina Dian Rahmawati. 2019. "Pengembangan Media Blended Learning Berbasis Edmodo Terhadap Hasil Belajar Membaca Teks Arab." Seminar Nasional Multidisiplin 2019: 144-52.

Sugiono. 2016. METODE PENELITIAN (Kuantitatif, Kualitatif, Dan R\&D. 1st ed. Bandung: Alfabeta CV.

Sukmana, Adi. (2020). Penilaian kinerja organisasi menggunakan metode key performance indikators (KPI): studi kasus: Himpunan Mahasiswa Teknik Industri Universitas Widyatama). Jurnal Ilmiah Teknologi Informasi terapan. 6 (2), 163-166.

Yasin, Muhammadin. (2013). Membangun Organisasi Berbudaya. Jakarta: Ekspose (PT Mizan Publika). 